\title{
Transient expression of clusterin (sulfated glycoprotein-2) during development of rat pancreas
}

\author{
B-H Min, S-Y Jeong ${ }^{3}$, S-W Kang, B G Crabo ${ }^{1}$, D N Foster ${ }^{1}$, \\ B-G Chun, M Bendayan ${ }^{2}$ and I-S Park ${ }^{3}$
}

Department of Pharmacology, College of Medicine, Korea University, Seoul, Korea 136-705, ${ }^{1}$ Department of Animal Science, University of Minnesota, St Paul, Minnesota 55108, USA, ${ }^{2}$ Department of Anatomy, University of Montreal, Montreal, Quebec, Canada H3C 3J7 and ${ }^{3}$ Department of Anatomy, College of Medicine, Inha University, Inchon, Korea 402-751

(Requests for offprints should be addressed to I-S Park, Department of Anatomy, College of Medicine, Inha University, Yonghyun-Dong, Nam-Gu, Inchon, Korea 402-751)

\begin{abstract}
Clusterin has been known to play important roles not only in remodeling damaged tissues, but also in tissue reorganization during embryonic development. In the present study, we have investigated the expression of clusterin in the endocrine pancreas during embryonic development. Although a weak immunoreaction was detected in some pancreatic primordial cells at day 14 of gestation, distinct clusterin expression was identified by immunocytochemistry and Northern blot analysis at the 16th day of gestation. Clusterin-producing cells, which corresponded to insulin-containing cells, accounted for the major portion of the developing islet of Langerhans up to 18 days of gestation. Thereafter, clusterin-producing cells display similar distribution and morphological features to glucagon-producing cells. Clusterin expressed in the pancreas was shown by Western blot analysis to be a disulfide-linked heterodimer of $70 \mathrm{kDa}$ with an $\alpha$-subunit of $32 \mathrm{kDa}$. During early developmental stages, however, we found that proteolytic internal cleavage of the clusterin
\end{abstract}

molecule occurred from the 18th day of gestation. Only one $70 \mathrm{kDa}$ band on the 16th day and two bands $(32 \mathrm{kDa}$ and $70 \mathrm{kDa}$ ) on the 18th day of gestation were detected by Western blot analysis even in reducing conditions, while only a single $32 \mathrm{kDa}$ band was detected on the second day after birth. The levels of clusterin mRNA in the pancreas transiently increased from the 16th day of gestation to the second day after birth, during the period when active cellular reorganization takes place to form the classic cellular features of the islet. Among various tissues (kidney, brain, liver, heart, lung and pancreas) the levels of clusterin mRNA were the highest in the pancreas from the 18th day of gestation to the second day after birth. In contrast, the lowest expression was observed in adult pancreatic tissue. The higher expression of clusterin in developing pancreas must indicate its involvement in tissue organization during development.

Journal of Endocrinology (1998) 158, 43-52

\section{Introduction}

Clusterin was first recognized and purified from ram rete testes fluid as a cell-aggregating factor (Blaschuk et al. 1983, Fritz et al. 1983). It is an acidic heterodimeric glycoprotein consisting of two different subunits of $40 \mathrm{kDa}$, joined by disulfide bonds (Blaschuk et al. 1983). Since then, it has been isolated and studied in various tissues. It has been reported as sulfated glycoprotein-2 from rat Sertoli cells (Griswold et al. 1986), apolipoprotein-J, SP-40,40 or complement cytolysis inhibitor in human serum (Murphy et al. 1988, Jenne \& Tschopp 1989, de Silva et al. 1990), testosterone repressed prostate message-2 in regressing rat ventral prostate (Leger et al. 1987), glycoprotein 80 from canine kidney cells (Hartmann et al. 1991), glycoprotein III from bovine adrenal chromaffin granules (Palmer \& Christie 1990), T64 from Japanese quail neuroretinal cells (Michel et al. 1989), pTB16 from human glioma (Danik et al. 1991), and pADHC-9 in the brain from a patient with Alzheimer's disease (May et al. 1989). As suggested from its widespread expression, it has been thought to be involved in numerous biological processes including spermatogenesis, immune regulation, lipid transport and apoptosis (Jenne \& Tschopp 1992, May \& Finch 1992, Tenniswood et al. 1992). However, these and other proposed functions need to be further characterized.

Silkensen et al. (1995) reported that clusterin induces aggregation and adhesion of renal epithelial cells. They suggested that clusterin promotes cell/cell and cell/ substratum interactions after renal injury, stabilizing cell membrane integrity at the epithelial barrier. Clusterin also has the ability to elicit clustering of a number of cells such as red blood cells and Sertoli cells (Fritz et al. 1983). French 
et al. (1993) reported that higher levels of clusterin expression occur during development in the branching bronchial tree of the embryonic lung tissue. Such a temporal expression of clusterin in developing lung tissue suggests that it could be involved in cell organization in various organ systems.

The pancreas is formed from exocrine and endocrine entities, the latter being composed of the islets of Langerhans. Pancreatic islets result from a dynamic histogenesis and begin to secrete insulin, glucagon and somatostatin at early fetal periods in the human.

Using in situ hybridization, Aronow et al. (1993) showed that clusterin is expressed in pancreatic acinar and ductal epithelial cells, but not in pancreatic islets. However, Scaglia et al. (1995), in agreement with the present study, showed that clusterin is mainly localized in the pancreatic islets. Furthermore, clusterin was assigned to glucagon cells in islets of adult rat. In the present study, we have investigated the expression of clusterin in pancreatic tissue during development, and show changes reflecting dynamic tissue reorganization during this period.

\section{Materials and Methods}

\section{Experimental animals and tissue preparation}

Sprague-Dawley rats were purchased from Charles River, St Constant, Quebec, Canada and DaeHan Experimental Animal Research Center, Seoul, Korea. They were mated and maintained at $20-22^{\circ} \mathrm{C}$ with alternating cycles of $12 \mathrm{~h}$ light and darkness, and fed ad libitum on a normal laboratory diet. The stage of fetal development was determined by the date of mating and by examination of the vaginal smear. The day that the vaginal plug appeared was designated day 1 of gestation. Fetuses were obtained by caesarean section on day 14, 16, 18 and 20 of gestation. Parturition of rats occurred on day 21 of gestation, and the day of birth was regarded as the first day of the neonatal period. Whole fetuses and pancreatic tissues from 1-, 2and 14-day-old rats were either fixed and processed for immunocytochemistry or rapidly frozen in liquid nitrogen for Northern and Western blot analysis. After fixation with Bouin or $4 \%$ paraformaldehyde solution, the tissues were embedded in paraffin or Epon resin respectively. Serial paraffin sections $(5 \mu \mathrm{m})$ and consecutive plastic sections $(1 \mu \mathrm{m})$ were mounted on poly-L-lysine coated glass slides.

\section{Preparation of clusterin antibody}

Clusterin antibody was prepared using a peptide portion of porcine clusterin $\alpha$-subunit as an immunogen ( $\mathrm{NH}_{2}$-GDRIDSLMENDRQQS-COOH; 1865.9 AMU (atomic mass units); amino acids 144-148; generated by standard fluorenylmethyloxycarbonyl solid-phase peptide synthesis and double purified by HPLC). The $\alpha$-peptide
$(2 \cdot 2 \mathrm{mg})$ was conjugated to $2 \mathrm{mg}$ cationized BSA via Imject SuperCarrier EDC system (Pierce, Rockford, IL, USA). The antigen was emulsified in Freund's complete adjuvant and injected subcutaneously into the back of a New Zealand White rabbit for primary immunization. Boosting was carried out at 2-3 weeks and immune serum was collected 10 days after the third injection.

\section{Immunocytochemistry}

The avidin-biotin-peroxidase complex method (Hsu et al. 1981) was performed on paraffin or Epon semi-thin sections as previously described (Park \& Bendayan 1992) using the specific anti-clusterin $\alpha$-peptide antibody. Briefly, the deparaffinized or deplasticized sections were immersed in normal goat serum and incubated for $24 \mathrm{~h}$ at $4{ }^{\circ} \mathrm{C}$ with the anti-clusterin $\alpha$-peptide antibody diluted 1:1000 with 0.01 M PBS. After a wash with PBS, biotinylated goat anti-rabbit immunoglobulin and avidin-biotin-peroxidase complex (ABC kit; Vector Labs, Burlingame, CA, USA) were each applied for $1 \mathrm{~h}$. Thereafter, the immunocytochemical reaction was revealed using diaminobenzidine solution. To illustrate the relation of clusterin-immunoreactive cells to the pancreatic hormone-secreting cells, double immunostaining was carried out on the same sections, as described previously (Park \& Bendayan 1992). After being immunostained for clusterin, the tissue sections were treated for $60 \mathrm{~s}$ with vigorous agitation in a solution composed of $0 \cdot 25 \%$ potassium permanganate (1 volume), $5 \% \mathrm{H}_{2} \mathrm{SO}_{4}$ (1 volume) and distilled water (140 volumes) in order to elute tissue-bound clusterin antibody as well as the linked antibody. The sections were then immunostained with mouse monoclonal anti-insulin (1:2000; BioGenex, San Ramon, CA, USA) or rabbit anti-glucagon (1:1000; Dako, Carpinteria, CA, USA) and rabbit anti-somatostatin (1:1500, ICN Corp., Stillwater, MN, USA) antibodies. The second immunoreaction was detected by nickel/ diaminobenzidine substrate providing a black reaction product, which was easily differentiated from the brown coloration of the diaminobenzidine substrate in the previously stained section.

\section{Control test of clusterin antibody}

Control experiments were performed to assess the specificity of the clusterin antibody. The primary antibody was preadsorbed with its corresponding antigen before immunocytochemical staining. For antigen adsorption, the optimally diluted antibody was allowed to react overnight with excess amounts of the clusterin peptide $(20 \mu \mathrm{g} / \mathrm{ml})$ that was used for antibody production. This preadsorbed antibody was substituted for the untreated primary antibody in the process of immunostaining. Immunodot experiments were performed on a nitrocellulose membrane in order to confirm the absence of cross-reactivity 
between clusterin and glucagon antibodies. Solutions containing clusterin or glucagon (Sigma, St Louis, MO, USA) were applied dropwise to membrane strips, air-dried, and incubated overnight with the anti-clusterin antibody or anti-glucagon antibody. The reaction signal was detected by the Western blotting method.

\section{Western blot analysis}

Pancreatic tissues were minced with scissors and homogenized in $1 \mathrm{ml}$ lysis buffer $(25 \mathrm{mM}$ Tris $/ \mathrm{HCl}$, $\mathrm{pH} 7 \cdot 4,1.0 \mathrm{mM}$ EDTA, $0.5 \%$ Triton X-100) with a Dounce homogenizer. The homogenate was subjected to centrifugation at $100000 \boldsymbol{g}$ for $1 \mathrm{~h}$. The supernatant was collected and used for protein determination using the Bio-Rad protein assay kit (Bio-Rad, Richmond, CA, USA). Protein samples $(50 \mu \mathrm{g})$ were denatured in reducing buffer $(60 \mathrm{mM}$ Tris $/ \mathrm{HCl}, \mathrm{pH} 6 \cdot 8,25 \%$ glycerol, $2 \%$ SDS, $14.4 \mathrm{mM} \beta$-mercaptoethanol and $0.1 \%$ bromophenol blue) and separated by electrophoresis on an SDS-(10\%) polyacrylamide gel. The separated proteins were transferred on to a nitrocellulose membrane using the transfer buffer $(39 \mathrm{mM}$ glycine, $48 \mathrm{mM}$ Tris $\mathrm{pH} 8 \cdot 3$, 0.037\% SDS, $20 \%$ methanol) at $200 \mathrm{~mA}$ for $4 \mathrm{~h}$. Western immunoblot analysis was performed using the protocols of BM Chemiluminescence Western Blotting Kit (Boehringer, Mannheim, Germany). The membrane was blocked with $1 \%$ blocking solution for $1 \mathrm{~h}$ at room temperature, and then incubated with the rabbit anticlusterin $\alpha$-peptide antibody (1:5000 dilution) in $0.5 \%$ blocking solution for $24 \mathrm{~h}$ at $4{ }^{\circ} \mathrm{C}$. The blot was washed in Tris-buffered saline containing $0 \cdot 2 \%$ Tween 20 (TBST), incubated with horseradish peroxidase conjugated to an anti-rabbit $\operatorname{IgG}$ in $0.5 \%$ blocking solution for $1 \mathrm{~h}$ at room temperature, and washed again in TBST. Detection was carried out with chemiluminescence substrate solution for $1 \mathrm{~min}$.

\section{Northern blot analysis}

Total RNA was isolated from fetal and neonatal pancreas by the acid guanidinium thiocyanate and phenol/chloroform extraction method as described by Chomczynski \& Sacchi (1987). RNA samples from kidney, brain, liver, heart and lung were prepared from 18-day-old fetal tissue, 2-day-old neonates and adult rats. Total RNA $(10 \mu \mathrm{g})$ was denatured, fractionated in a $1.2 \%$ agarose gel containing $0.67 \mathrm{M}$ formaldehyde, and transferred to positively charged Hybond-N+ nylon membrane (Amersham, Arlington Heights, IL, USA) by capillary action with $10 \times$ SSC. Membranes were baked at $120{ }^{\circ} \mathrm{C}$ for $30 \mathrm{~min}$ and prehybridized in hybridization buffer $(50 \%$ formamide, $1.5 \times$ SSC, $5 \times$ Denhardt's reagent, $1 \cdot 0 \%$ SDS, $20 \mathrm{mM}$ sodium phosphate, $\mathrm{pH} 7 \cdot 0$, and $100 \mu \mathrm{g} / \mathrm{ml}$ yeast RNA) at $55^{\circ} \mathrm{C}$ for $2 \mathrm{~h}$. The $350 \mathrm{bp}$ clusterin cDNA was amplified by PCR using $5^{\prime}$ primer
(cgggtaccGACAATGAGCTCCA) and 3' primer (ggccg cggCCACTCCTGCAGAC) and cloned into pBluescript $\mathrm{ks}(+)$. T7 RNA polymerase was used to generate $\left[\alpha-{ }^{32} \mathrm{P}\right]$ UTP-labeled cRNA antisense probe $\left(2 \times 10^{6}\right.$ c.p.m. $/ \mathrm{ml}$ ). After hybridization with the probe at $55^{\circ} \mathrm{C}$ for $16 \mathrm{~h}$, the membranes were washed twice in $0 \cdot 5 \times \mathrm{SSC} / 0 \cdot 1 \% \mathrm{SDS}$ at room temperature for $16 \mathrm{~min}$ each, and more stringently once in $0 \cdot 2 \times \mathrm{SSC} / 0 \cdot 1 \% \mathrm{SDS}$ at $65{ }^{\circ} \mathrm{C}$ for $30-45 \mathrm{~min}$. The membranes were then exposed to $\mathrm{X}$-ray film with an intensifying screen at $-80{ }^{\circ} \mathrm{C}$ for 2 days.

\section{Results}

\section{Immunoreactivity of clusterin in developing rat pancreas}

To follow the expression of clusterin in the developing pancreas, whole embryo or pancreatic tissues at different stages of development were fixed and processed for immunocytochemistry using the specific antibody against a clusterin $\alpha$-subunit peptide. In the fetus at 12 days of gestation, the pancreatic bud or primordium was seen in the vicinity of the foregut. Clusterin immunoreactivity, however, was not detected in the pancreatic primordium at this stage, while glucagon-immunoreactive cells were already present (Fig. 1a and b). In most of the embryonic pancreas, clusterin immunoreactivity began to be identified distinctly in the islets on the 16th day of gestation, although a very weak immunoreaction was detected in a few endocrine cells at day 14 of gestation (Fig. 1c and 2b). Insulin-immunoreactive cells were also found at the 16th day of gestation as previously reported (Park \& Bendayan 1993). Subsequently, numerous clusterin immunoreactive cells which showed a similar distribution to the insulin and glucagon cells were found in the embryonic pancreatic islets on the 18th day of gestation. In 2-day-old neonatal tissue, however, clusterin immunoreactivity was shown to be present and to have a distribution similar to that of the glucagon cells at the periphery of the islets, whereas insulin was expressed in $\beta$ cells at the center of the islets. Staining of serial sections and double-labeling methods revealed that clusterin is expressed not only in insulin-secreting $\beta$ cells, but also in glucagon-secreting $\alpha$ cells during development. Most clusterin cells present in the fetal pancreas at 18 days of gestation showed strong immunoreactivity for insulin (Fig. 3a and b). At 20 days of gestation, however, insulin-immunoreactive cells demonstrated a weak to moderate positive reaction for clusterin (Fig. $3 \mathrm{c}$ and d). From that stage on, some clusterin-immunoreactive cells were found to correspond to glucagon cells at the periphery of the islet (Fig. 4). Clusterin, however, was not detected in the somatostatin-immunoreactive cells at any stage of development (Fig. 5). In control tests, no positive labeling was obtained when the sections were incubated with the preadsorbed antibody. In addition, immunodot 

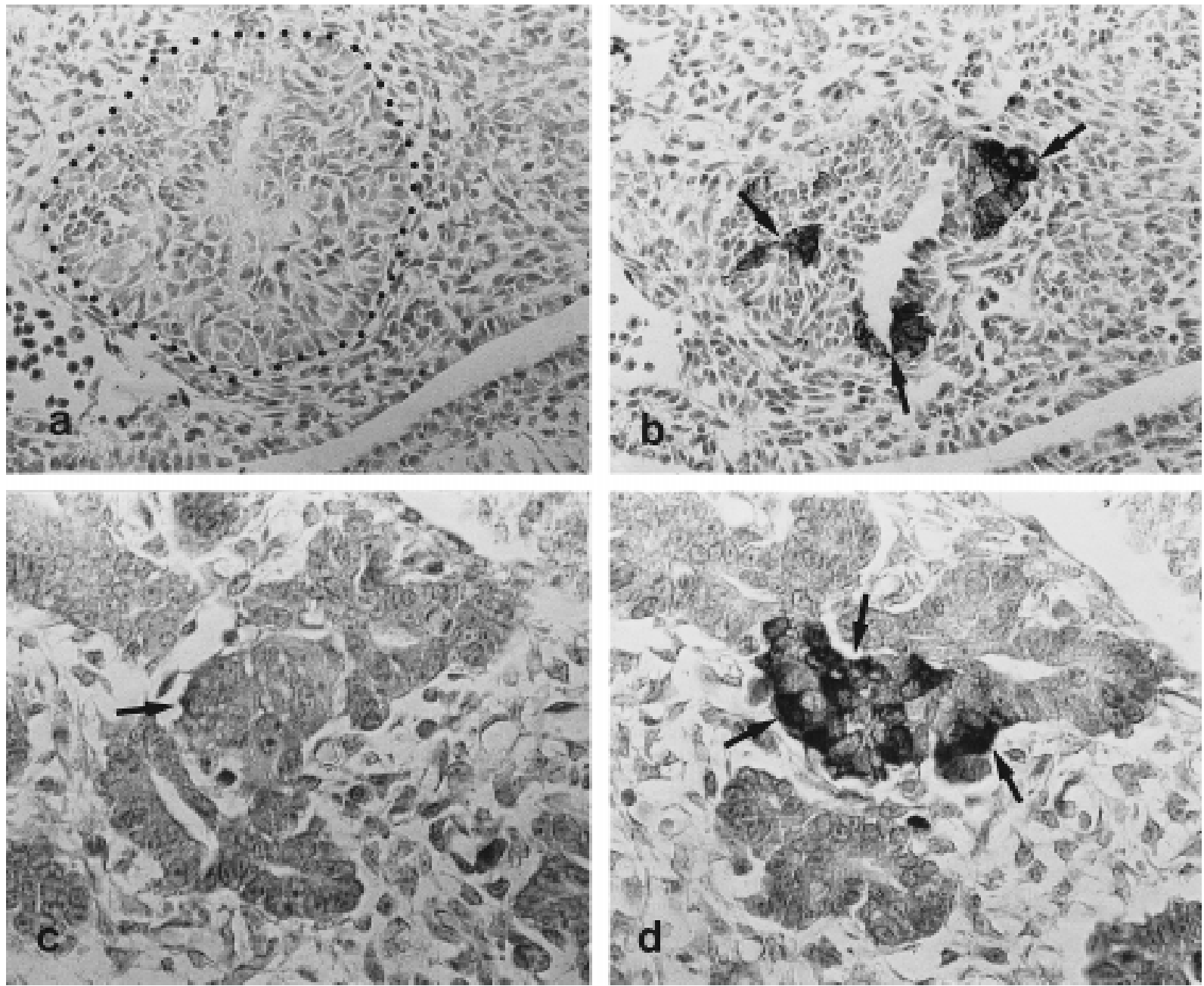

Figure 1 Immunoreactivity of clusterin and glucagon on the semi-serial transverse sections of the fetal rat at $12(\mathrm{a}, \mathrm{b})$ and $14(\mathrm{c}, \mathrm{d})$ days of gestation. Adjacent sections were incubated with anti-clusterin (a, c) or anti-glucagon antibodies (b, d). Clusterin immunoreactivity was absent in pancreatic primordium at day 12 , and a very weak immunoreaction began to be detected in a few endocrine cells of the pancreas at day 14 of gestation (arrow in c). In the adjacent sections, however, glucagon-immunoreactive cells appeared not only in the pancreatic primordium (arrows in b), but also in the embryonic pancreatic tissue (arrows in d). Area encircled by dotted line in (a) is pancreatic primordium. Magnification $\times 600$.

experiments showed no cross-reactivity between antibodies (data not illustrated).

Western blot analysis of clusterin in the fetal and neonatal pancreas

Clusterin has been known to display different molecular masses according to the tissue as the result of tissue-specific post-translational modifications (Blaschuk et al. 1983, Buttyan et al. 1989, Sylvester et al. 1991, Sensibar et al. 1993). The molecular mass of the clusterin expressed in developing rat pancreatic tissue was assessed by separating fetal and neonatal protein samples by SDS-PAGE under reducing conditions, followed by immunoblotting with the anti-clusterin $\alpha$-subunit antibody. Clusterin was shown to be present as a disulfide-linked heterodimer of $70 \mathrm{kDa}$ with an $\alpha$-subunit of $32 \mathrm{kDa}$ (Fig. 6). Although weak immunoreactivity was found for the pancreatic primordia at day 14 of gestation (Fig. 1c), clusterin was clearly detected by Western blot analysis in embryonic pancreas from the 16th day of gestation. Interestingly we found that the specific $\alpha$-subunit antibody recognized only a $70 \mathrm{kDa}$ polypeptide under reducing conditions, suggesting that no internal proteolytic cleavage had occurred by the 16th day of gestation. However, two immunoreactive bands ( 32 and $70 \mathrm{kDa}$ ) were detected in tissues from the 18th day of gestation, and only one $32 \mathrm{kDa}$ band on day 2 of the neonatal period. This suggests that internal 

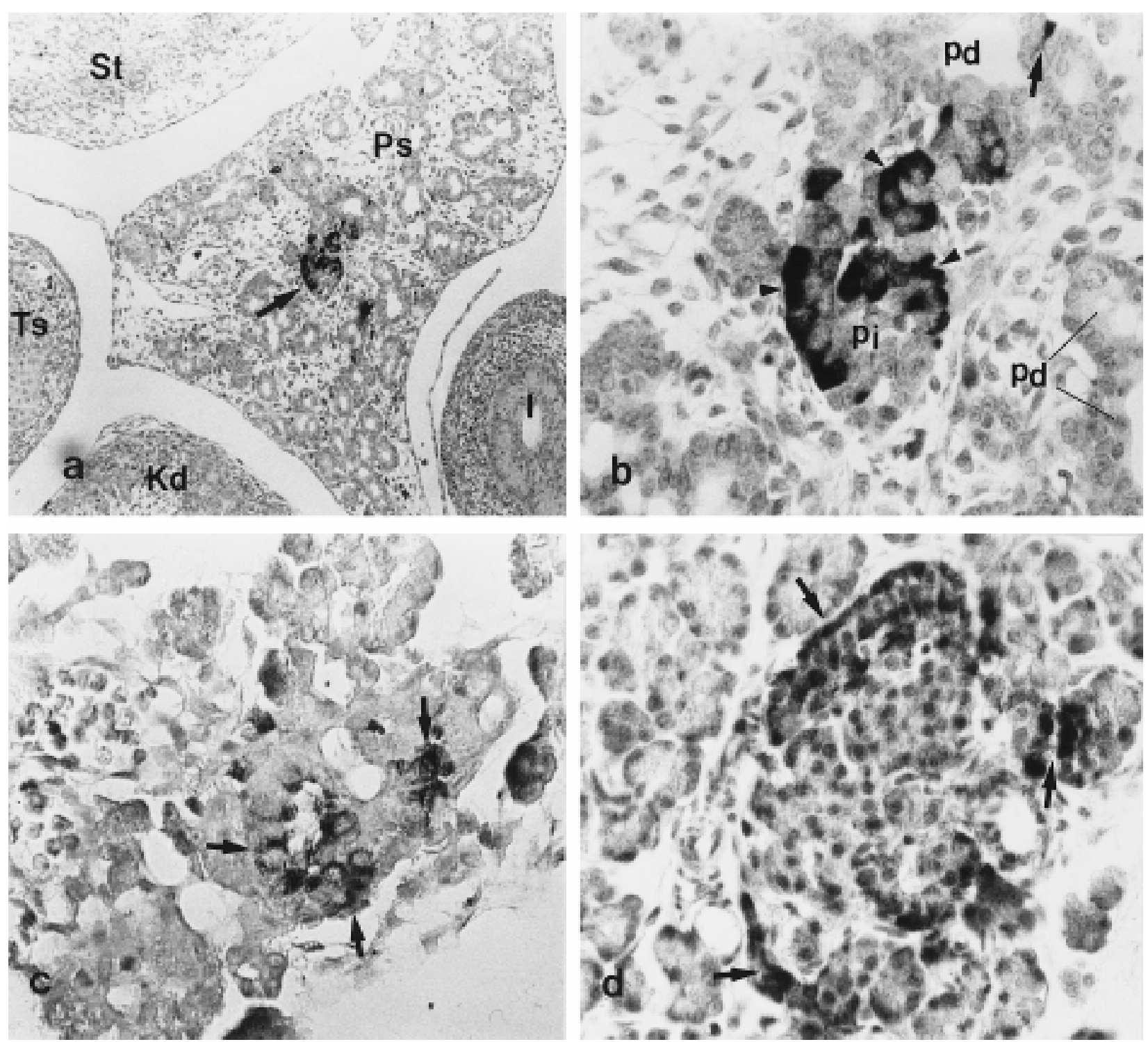

Figure 2 Immunoreactivity of clusterin on sections of the fetal rat at days 16 (a, b) and 18 (c) of gestation, and day 2 after birth (d). In the lower magnification $(\times 160)$ of the transverse section of the fetus at day 16 of gestation (a), clusterin immunoreactivity was distinctly observed in many cells (arrow in a) located in the central part of the embryonic pancreas (Ps) on the 16th day of gestation. At this stage, no clusterin immunoreactivity was seen in stomach (St), testis (Ts), kidney (Kd) or intestine (I). In the higher magnification (b, $\times 600)$, clusterin cells (arrowheads) were predominantly seen in the developing pancreatic islet (pi), while some of them (arrow) were located in the epithelial lining of the embryonic pancreatic duct (pd), which gives rise to islet or acinar tissues during development. Although they were shown in the center of the islet at day 18 of gestation (arrows in c), most clusterin cells were distributed at the periphery of the pancreatic islet at 2 weeks after birth (arrows in d).

proteolytic cleavage of clusterin begins from the 18th day of gestation (Fig. 6).

Transient expression in developing pancreas and tissue distribution of clusterin $m R N A$

The clusterin gene was highly expressed in the pancreas on the 16th day of gestation, while little expression was observed on the 14th day. The levels of clusterin mRNA were increased about 5- to 7-fold on the second day after birth compared with the 18th day of gestation and returned to very low expression levels in adult pancreas (Fig. 7). When compared with other tissues (kidney, brain, liver, heart, lung and pancreas) at the same stages of development, the highest level of clusterin mRNA was detected in the pancreas on the 18th day of gestation and 

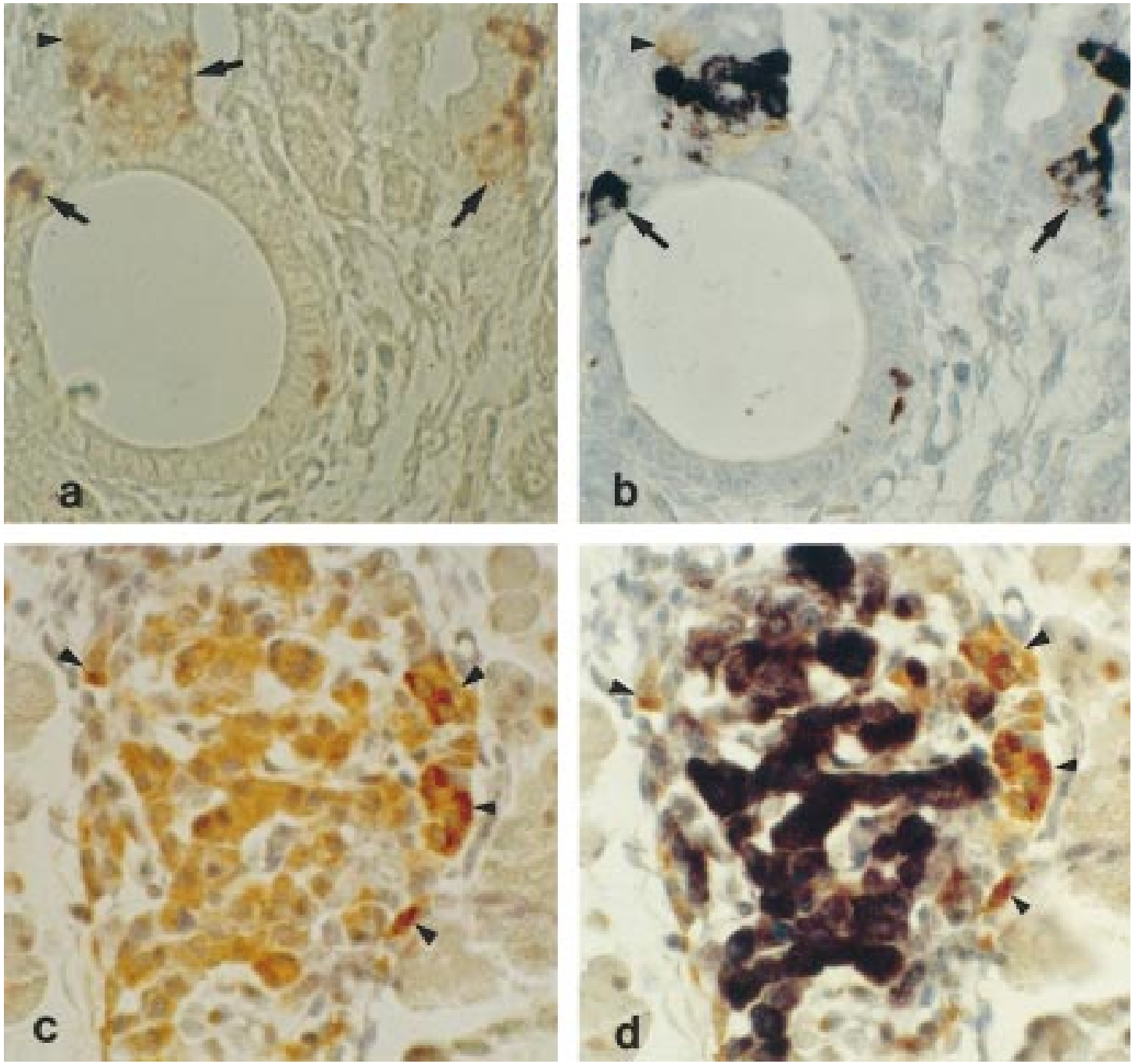

Figure 3 Double-staining experiment using clusterin $(a, c)$ and insulin (b, d) antibodies in the same paraffin section of pancreatic tissues at day $18(\mathrm{a}, \mathrm{b})$ and 20 (c, d) of gestation. At day 18 of gestation, most clusterin-immunoreactive cells showing the brown reaction product of diaminobenzidine (arrows in a) were also stained by insulin antibody with the black color reaction of $\mathrm{Ni} /$ diaminobenzidine (arrows in b). One clusterin-staining cell showed no insulin immunoreactivity (arrowhead in a and b). At day 20 of gestation, clusterin-staining cells in the central portion of the islet were double labeled with insulin antibody, while the cells at the periphery showing higher clusterin immunoreactivity (arrowheads in c and d) were devoid of insulin. Magnification $\times 600$.

on the second day after birth (Fig. 8A and B). The lowest level of expression was observed in adult pancreatic tissue (Fig. 8C). The tissue-specific expression of clusterin in normal adult rat showed that the steady-state levels of clusterin mRNA were very high in normal brain and relatively high in lung, heart and liver; however, levels were very low in kidney and pancreatic tissues of adult rat (Fig. 8C).

\section{Discussion}

Clusterin has been known to be involved in tissue remodeling, differentiation, morphogenesis and apoptotic cell death in developmental tissues as well as damaged ones (Jenne \& Tschopp 1992, May \& Finch 1992, Tenniswood et al. 1992, French et al. 1993, Thomas-Salgar \& Millis 1994). The pancreas has been shown to secrete endocrine hormones through its islets of Langerhans during very early developmental stages (Pictet \& Rutter 1972). Its endocrine portion is elaborated from the specialized cell clusters originating from the primitive pancreatic duct by the dynamic processes of cell division, migration and differentiation. In the present study, we have examined the expression of clusterin in the developing pancreas and observed that it is already present in embryonic cells as early as day 16 of gestation and increases to reach the 

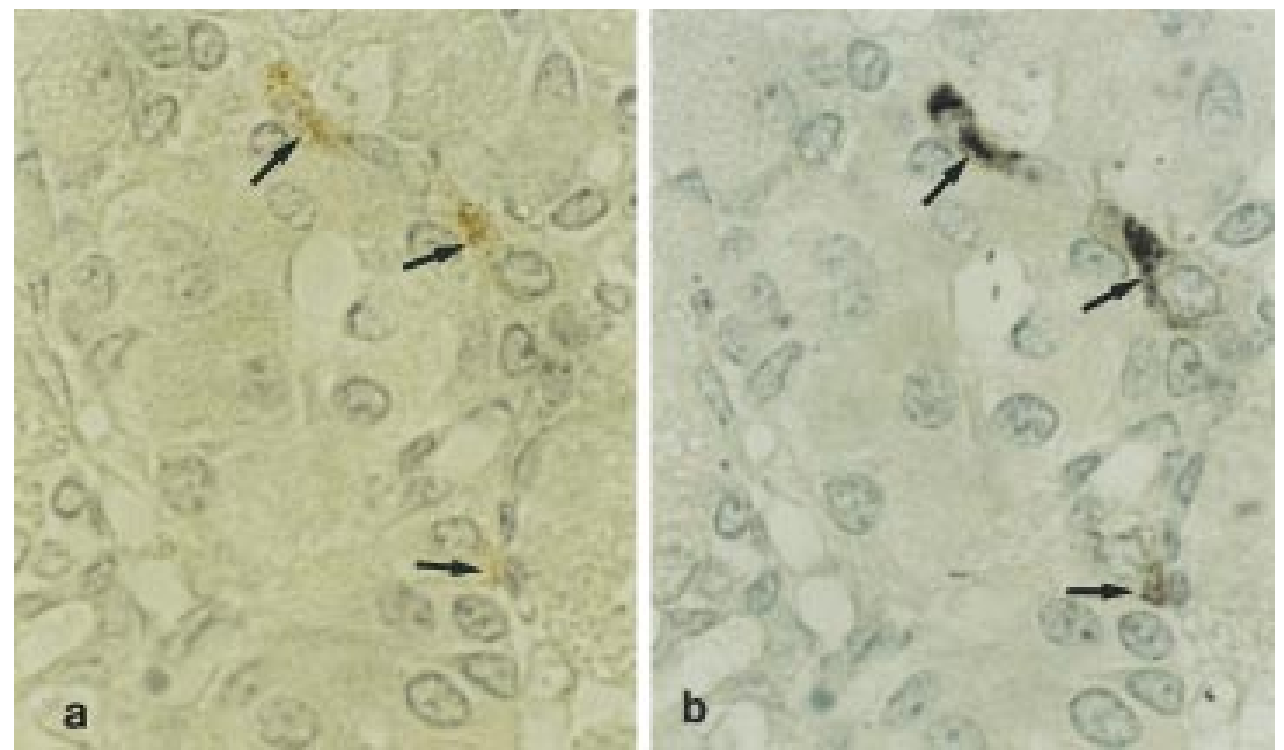

Figure 4 Double immunoreaction with clusterin and glucagon antibodies in the same paraffin sections of fetal pancreas at day 20 of gestation. All of the clusterin cells at the periphery of the islet (arrows in a) were immunoreactive with glucagon antibody (arrows in b). Magnification $\times 1400$.
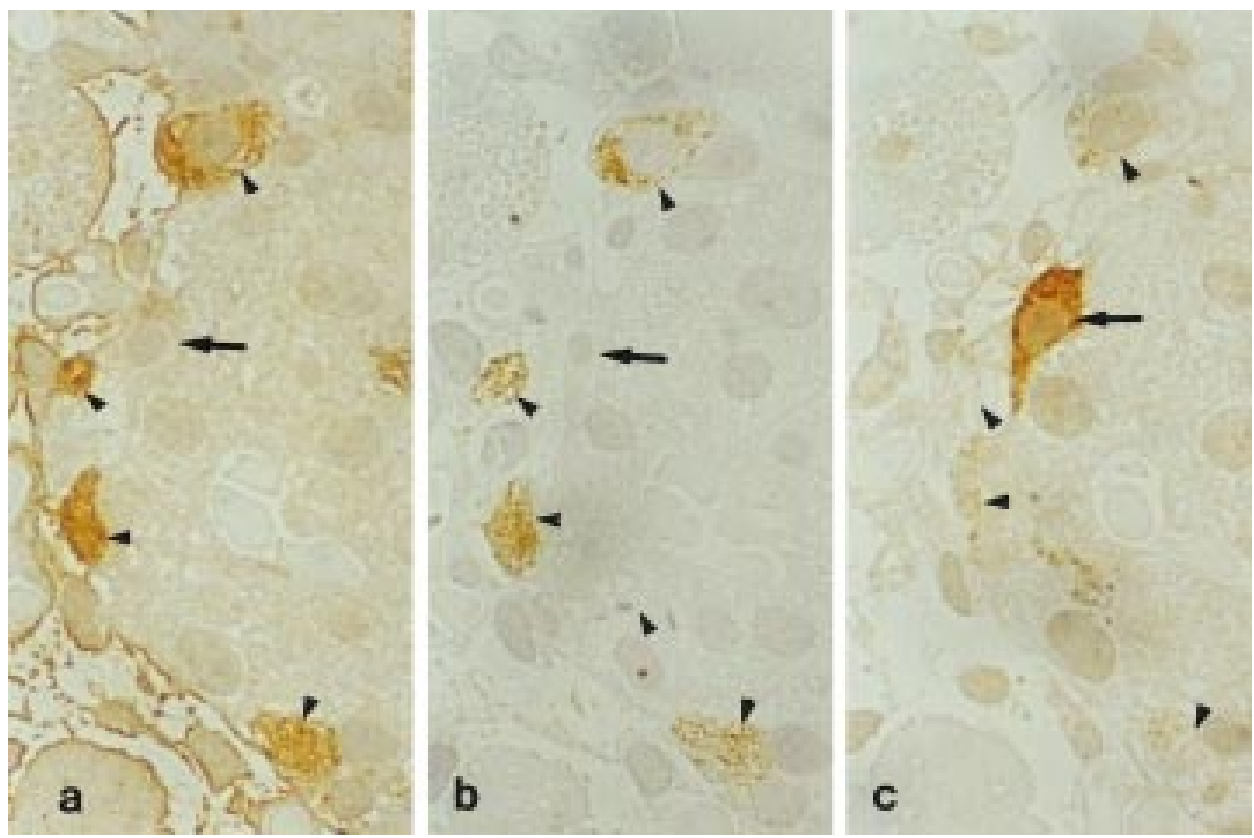

Figure 5 Serial semi-thin sections of pancreatic tissues of rat on the first day of birth. Three adjacent sections were labeled for glucagon (a), clusterin (b) and somatostatin antibodies (c). Four islet cells indicated by arrowheads in (a) and (b) were simultaneously immunolabeled by clusterin and glucagon. A somatostatin cell (arrow in c) showed no immunoreaction for glucagon or clusterin antibodies (arrow in $\mathrm{a}$ and $\mathrm{b}$ respectively). Magnification $\times 1400$.

highest levels at early postneonatal stages, as demonstrated by both immunocytochemistry and Northern blot analysis. Clusterin immunoreactivity was detected in embryonic endocrine-type cells, which bud from the primitive duct to the newly emerging pancreatic islets on the 18th day of gestation. At day 18, clusterin immunoreactivity was co-localized to insulin- and glucagon-producing cells. This implies that clusterin may play a role in aggregating the endocrine cells originating and migrating from the developing duct to form the complex islet organization. 


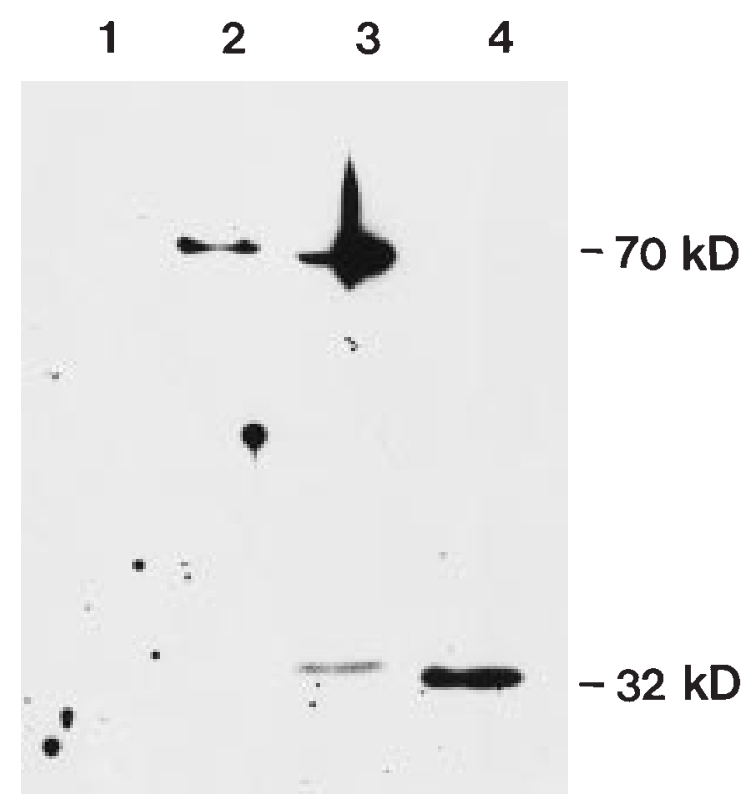

Figure 6 Western blot analysis of clusterin in the rat pancreas during development. Pancreatic protein samples $(50 \mu \mathrm{g})$ of fetuses at day 14 (lane 1), 16 (lane 2), 18 (lane 3 ) of gestation, and 2 days after birth (lane 4) were separated by SDS-PAGE under reducing conditions, and processed for immunoblotting with anti-clusterin antibody as described in Materials and Methods. Clusterin was detected from the embryonic pancreas as early as day 16 of gestation, while internal proteolytic cleavage processing was shown to occur from day 18 of gestation. kD, kDa.

Thus clusterin could be an aggregating molecule involved in the organization of the pancreatic islet. This is supported by the demonstration that renal epithelial cells in culture aggregate only in the presence of clusterin (Silkensen et al. 1995). It is also strengthened by the demonstration that clusterin gradually becomes restricted to specialized cells after the formation of the pancreatic islets in the neonatal period. The presence of clusterin immunoreactivity at the periphery of pancreatic islets at the postneonatal stage is in agreement with a previous report showing its presence in non- $\beta$ cells in the adult pancreatic islet (Scaglia et al. 1995), but contradicts the results of Aronow et al. (1993), who reported the presence of clusterin mRNA in acinar and ductal epithelial cells but not in islet cells of the adult pancreas. There is at present no clear explanation for this discrepancy. However, $1.6 \mathrm{~kb}$ clusterin riboprobe and $5^{\prime}$-end $220 \mathrm{bp}$ riboprobe were found to bind $28 \mathrm{~S}$ rRNA, even when highly stringent conditions were used during our Northern blot experiments (data not shown). Such non-specific binding led us to work with an internal region riboprobe (see Materials and Methods) which, under highly stringent hybridization conditions, reduced background binding. The clusterin in cells at the neonatal stage may participate in maintaining the particular aggregation and cellular organization of the islet cells.
A

$\begin{array}{lllll}\text { F14 } & \text { F16 } & \text { F18 } & \text { N2 } & \text { A }\end{array}$

$2.0 \mathrm{~kb}$ -

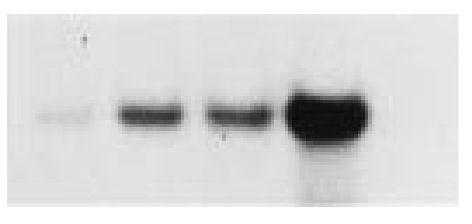

B

\section{$\begin{array}{lllll}\text { F14 } & \text { F16 F18 } & \text { N2 } & \text { A }\end{array}$}

$18 S$ -

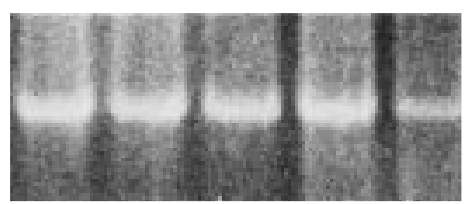

Figure 7 Northern blot analysis of clusterin mRNA during pancreatic development. Each lane contained $10 \mu \mathrm{g}$ total RNA isolated from pancreatic tissue of fetuses at day 14, 16, 18 of gestation (F14-F16), day 2 after birth (N2) and adult (A). Equality of RNA loading was demonstrated by the ethidium bromide staining of $18 \mathrm{~S}$ rRNA in (B).

The molecular mass of clusterin in rat pancreas was shown to be $70 \mathrm{kDa}$, with an $\alpha$-subunit of $32 \mathrm{kDa}$ linked by disulfide bonds. However, when an antibody against the clusterin $\alpha$-subunit peptide was used under reducing conditions, only one $70 \mathrm{kDa}$ polypeptide band was detected at day 16 of gestation, while two bands $(70 \mathrm{kDa}$, $32 \mathrm{kDa}$ ) were detected at day 18 , and only one $32 \mathrm{kDa}$ band was detected at day 2 after birth, suggesting that internal proteolytic cleavage begins at day 18 of gestation. This is the first report to show regulated developmental proteolytic cleavage of clusterin in the pancreas. The significance of this transformation and proteolytic cleavage may be related to differences in cellular expression and to the organization of islet cells during embryonic development. Northern blot analysis was unable to detect clusterin transcripts in adult pancreatic tissue (Fig. 8C), whereas weak clusterin immunoreactivity was identified in pancreatic islets. This may be due to decreases in both the volume density of the endocrine pancreas and the number of islets per unit area in adult compared with neonatal tissues (Massa et al. 1997). During development, however, the highest level of clusterin message was observed in pancreatic tissues between the 18th day of gestation and 2 days after birth (Fig. 8A and B). High levels of clusterin expression were also found in adult normal rat brain and lung as reported previously (French et al. 1993, Wong et al. 1994). 
(A)

\section{$2.0 \mathrm{~kb}$ -}

$18 \mathrm{~S}$

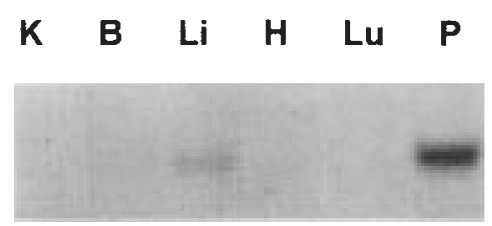

(B)

\section{$2.0 \mathrm{~kb}$ -}

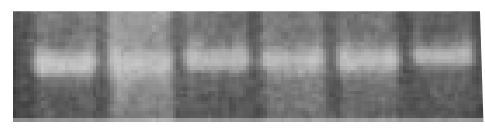

$18 S$

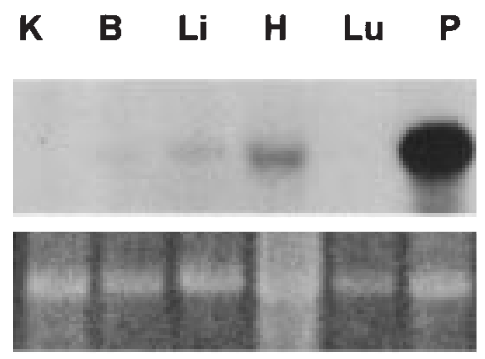

(C)

$2.0 \mathrm{~kb}$ -
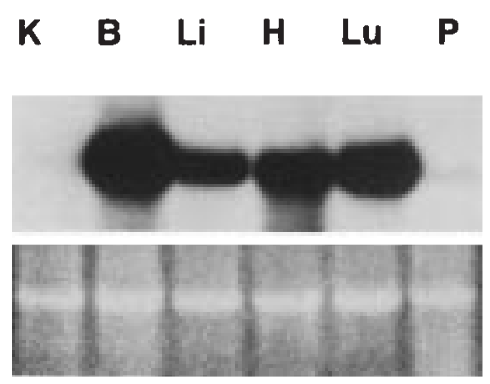

Figure 8 Northern blot analysis of clusterin mRNA. Each lane contained $10 \mu \mathrm{g}$ total RNA isolated from kidney $(\mathrm{K})$, brain (B), liver $(\mathrm{Li})$, heart $(\mathrm{H})$, lung $(\mathrm{Lu})$ or pancreas $(\mathrm{P})$ at day 18 of gestation $(\mathrm{A})$, day 2 after birth (B) and in the adult (C). Equality of RNA loading was demonstrated by the ethidium bromide staining of $18 \mathrm{~S}$ rRNA.

In summary, high levels of clusterin expression in actively developing pancreatic islets and developmental modification suggest that clusterin may play important roles in the organization of the endocrine islets through cell aggregation or tissue remodeling.

\section{Acknowledgements}

This work was supported by KOSEF (95-0403-05-02-3).

\section{References}

Aronow BJ, Lund SD, Brown TL, Harmony JA \& Witte DP 1993 Apolipoprotein J expression at fluid-tissue interfaces: potential role in barrier cytoprotection. Proceedings of the National Academy of Sciences of the USA $90725-729$.
Blaschuk O, Burdzy K \& Fritz IB 1983 Purification and characterization of a cell-aggregating factor (clusterin), the major glycoprotein in ram rete testis fluid. Journal of Biological Chemistry $2587714-7720$.

Buttyan R, Olsson CA, Pintar J, Chang C, Bandyk M, Ng PY \& Sawczuk IS 1989 Induction of the TR.p.m.-2 gene in cells undergoing programmed death. Molecular and Cellular Biology 9 3473-3481.

Chomczynski P \& Sacchi N 1987 Single step method for RNA isolation by acid guanidinium thiocyanate-phenol-chloroform extraction. Analytical Biochemistry 162 166-169.

Danik M, Chabot JG, Mercier C, Benabid AL, Chauvin C, Quirion R \& Suh M 1991 Human gliomas and epileptic foci express high levels of a mRNA related to rat testicular sulfated glycoprotein 2, a purported marker of cell death. Proceedings of the National Academy of Sciences of the USA 88 8577-8581.

French LE, Chonn A, Ducrest D, Baumann B, Belin D, Wohlwend A, Kiss JZ, Sappino AP, Tschopp J \& Schifferli JA 1993 Murine clusterin: molecular cloning and mRNA localization of a gene associated with epithelial differentiation processes during embryogenesis. Journal of Cell Biology 122 1219-1240.

Fritz IB, Burdzy K, Setchell B \& Blaschuk O 1983 Ram rete testis fluid contains a protein (clusterin) which influences cell-cell interactions in vitro. Biology of Reproduction 28 1283-1288.

Griswold MD, Roberts K \& Bishop P 1986 Purification and characterization of a sulfated glycoprotein secreted by Sertoli cells. Biochemistry 25 7265-7270.

Hartmann K, Rauch J, Urban J, Parczyk K, Diel P, Pilarsky C, Appel D, Haase W, Mann K, Weller A \& Kosh-Brandt C 1991 Molecular cloning of gp 80, a glycoprotein complex secreted by kidney cells in vitro and in vivo. A link to the reproductive system and to the complement cascade. Journal of Biological Chemistry 266 9924-9931.

Hsu SM, Raine L \& Fanger H 1981 Use of avidin-biotin-peroxidase complex $(\mathrm{ABC})$ in immunoperoxidase techniques: a comparison between $\mathrm{ABC}$ and unlabeled antibody (PAP) procedures. Journal of Histochemistry and Cytochemistry 29 577-580.

Jenne DE \& Tschopp J 1989 Molecular structure and functional characterization of a human complement cytolysis inhibitor found in blood and seminal plasma: identity to sulfated glycoprotein 2, a constituent of rat testis fluid. Proceedings of the National Academy of Sciences of the USA 86 7123-7127.

Jenne DE \& Tschopp J 1992 Clusterin: the intriguing guises of a widely expressed glycoprotein. Trends in Biochemical Science $\mathbf{1 8}$ 164-169.

Leger JG, Montpetit ML \& Tenniswood MP 1987 Characterization and cloning of androgen-repressed mRNAs from rat ventral prostate. Biochemical and Biophysical Research Communications 147 196-203.

Massa L, Zotto HD, Gomez Dumm CLA \& Gagliardino JJ 1997 Postnatal sequential changes in islet morphology and insulin secretion of normal hamsters. Pancreas 14 58-64.

May PC \& Finch CE 1992 Sulfated glycoprotein 2: new relationships of this multifunctional protein to neurodegeneration. Trends in Neuroscience 16 391-396.

May PC, Johnson SA, Poirier J, Lampert-Etchells M \& Finch CE 1989 Altered gene expression in Alzheimer's disease brain tissue. Canadian Journal of Neurological Sciences 16 473-476.

Michel D, Gillet G, Volovitch M, Pessac B, Calothy G \& Brun G 1989 Expression of a novel gene encoding a $51.5 \mathrm{kD}$ precursor protein is induced by different retroviral oncogenes in quail neuroretinal cells. Oncogene Research 4 127-146.

Murphy BF, Kirszbaum L, Walker ID \& d'Apice AJ 1988 SP-40,40, a newly identified normal human serum protein found in the SC5b-9 complex of complement and in the immune deposits in glomerulonephritis. Journal of Clinical Investigation 81 1858-1864.

Palmer DJ \& Christie DL 1990 The primary structure of glycoprotein III from bovine adrenal medullary chromaffin granules. Sequence 
similarity with human serum protein-40,40 and rat Sertoli cell glycoprotein. Journal of Biological Chemistry 265 6618-6623.

Park IS \& Bendayan M.1992 Coexistence of glucagon and pancreatic polypeptide in human and rat pancreatic endocrine cells. Endocrine Pathology 3 144-143.

Park IS \& Bendayan M 1993 Development of the endocrine cells in the rat pancreatic and bile duct system. Histochemical Journal $\mathbf{2 5}$ 807-820.

Pictet R \& Rutter WJ 1972 Development of the embryonic endocrine pancreas. In The Endocrine Pancreas, Handbook of Physiology, section 7, vol 1, pp 1-23. Eds D Steiner \& N Fteinkel. Washington DC: William \& Wilkins.

Scaglia L, Smith FE \& Bonner-Weir S 1995 Apoptosis contributes to the involution of beta cell mass in the post partum rat pancreas. Endocrinology 146 5461-5468.

Sensibar JA, Qian Y, Griswold MD, Sylvester SR, Bardin CW, Cheng CY \& Lee C 1993 Localization and molecular heterogeneity of sulfated glycoprotein-2 (clusterin) among ventral prostate, seminal vesicle, testis, and epididymis of rats. Biology of Reproduction 49 233-242.

Silkensen JR, Skubitz KM, Skubitz AP, Chmielewski DH, Manivel JC, Dvergsten JA \& Rosenberg ME 1995 Clusterin promotes the aggregation and adhesion of renal porcine epithelial cells. Journal of Clinical Investigation 96 2646-2653. de Silva HV, Stuart WD, Duvic CR, Wetterau JR, Ray MJ, Ferguson DG, Albers HW, Smith WR \& Harmony JA 1990 A $70-\mathrm{kDa}$ apolipoprotein designated ApoJ is a marker for subclasses of human plasma high density lipoproteins. Journal of Biological Chemistry 265 14240-14247.

Sylvester SR, Morales C, Oko R \& Griswold MD 1991 Localization of sulfated glycoprotein-2 (clusterin) on spermatozoa and in the reproductive tract of the male rat. Biology of Reproduction $\mathbf{4 5}$ 195-207.

Tenniswood MP, Guenette RS, Lakins J, Mooibroek M, Wong P \& Welsh JE 1992 Active cell death in hormone-dependent tissues. Cancer and Metastasis Reviews 12 197-220.

Thomas-Salgar S \& Millis AJ 1994 Clusterin expression in differentiating smooth muscle cells. Journal of Biological Chemistry 269 18879-18885.

Wong P, Taillefer D, Lakins J, Pineault J, Chader G \& Tenniswood M 1994 Molecular characterization of human TR.p.m.-2/clusterin, a gene associated with sperm maturation, apoptosis and neurodegeneration. European Journal of Biochemistry 221 918-925.

Received 9 September 1997

Revised manuscript received 27 January 1998 Accepted 16 February 1998 